\title{
ウロキナーゼの目合変化に関する研究"1
}

\author{
村瀬勢津子, 遠山啓子, 関 京子, 加賀谷繁, 朝長文弥*2, 中川輝昭*2a \\ 北里大学病院薬郕部*2
}

\section{Study on Compatibility of Urokinase with Other Drugs*1}

\author{
Setsuko Murase, Keiko Toyama, Kyoko Seki, Hazime Kagaya, \\ FUMIYA TOMONAGA*2, and TERUAKI NAKAGAWA*2a \\ Pharmacy, Kitasato University Hospital*2
}

(Received October 21, 1981)

\begin{abstract}
Compatibility tests on Urokinase (UK) with 39 kinds of drugs prescribed in combination with UK in our hospital were performed in terms of visible change, $\mathrm{pH}$ and residual potency of UK as determined by fibrin-plate method after the mixture. The results may be summarized as follows:

1) Mixture of UK and Calcicol or Persantin showed precipitation immediately after mixing, while mixture of UK and Keflin, K. C. L., Penbritin or Celtol showed a decrease in potency $0-3$ hours after mixing. Therefore, these mixtures are incompatible.

2) Mixture of UK and Solita $\mathrm{T}_{3}$, Pydoxal, Vitamedin, Vitaneurin, MDS or Novoheparin showed a decrease in potency 6 hours after mixing. Hence these mixtures should be made carefully.
\end{abstract}

Keywords_-urokinase ; mixture ; fibrin-plate method ; residual potency ; infusion ; antibiotic ; antineopastic; vitamin

\section{は じめに}

ウロキナーゼ（以下 UK と略す）は血栓や塞栓症の 治療に血栓溶解剤として, また抗悪性腫湯剂との併用療 法など，その使用量は近年増加しつつある. それに伴い UK と他剤との混合使用も多くなってきているが，配合 変化に関する報告は今なお十分とはいえない.そこで著 者らは UK と39種の注射剂との配合変化について検討 し，多少の知見を得たので報告する。

\section{実 䀫 の 部}

\section{1. 英検材料および方法}

過去 1 年間の当院における注射笺をチェックしてみる と（Fig. 1); UK は補液をべースに抗生物質製剂（以下 抗生剤), 抗悪性腫噋剤およびビタミン剂などが混合さ

*1 第 9 回日本薬剤師会関東学術大会（横浜, 1979年） で発表.

*2 相模原市北里 1 丁目15-1；15-1，1-chome, Kitasato, Sagamihara-shi, 228 Japan

*2a 現：富山医科薬科大学病院薬郕部
れており，特に $2 \sim 5$ 種の混注が多かった. そこで今 回, これらの注射剂と 1:1の混合について検討した.

UK は 6,000 unit（ミドリ十字）を用い, 配合剤とし て補液類はグルノン (以下 GL), 低分子デキストラン (以下 $\mathrm{DX}),>$ フィザルッ (以下 $\mathrm{PZ})$ ， ハルトマン D, ラクテック, フィジオゾール 3 号, ソリタ $\mathrm{T}_{3}$ (以下 $\mathrm{ST}_{3}$ )

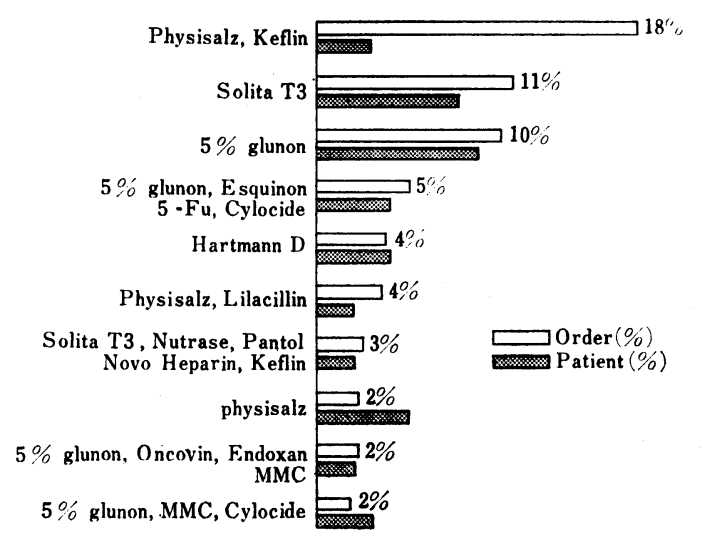

Fig. 1. Frequency of Use of Mixtures in Kitasato Hospital Pharmacy (1977) 
Table 1. Summary of Materials Investigated in Additive Combination Tested

\begin{tabular}{|c|c|c|c|c|}
\hline & Brand name & Amounts & Appearance & $\mathrm{pH}$ \\
\hline Urokinase & Urokinase & $6000 u n i t / 5 \mathrm{ml}$ & colorless & 7.0 \\
\hline Infusions & $\begin{array}{l}\text { Glunon } \\
\text { Dextran(low mol) } \\
\text { Physisalz } \\
\text { Hartmann D } \\
\text { Lactec } \\
\text { Physiosol } 3 \\
\text { Solita T3 } \\
\text { Peri-Solita }\end{array}$ & $\begin{array}{l}500 \mathrm{ml}(5 \%) \\
500 \mathrm{ml} \\
500 \mathrm{ml} \\
500 \mathrm{ml} \\
500 \mathrm{ml} \\
500 \mathrm{ml} \\
500 \mathrm{ml} \\
1000 \mathrm{ml}\end{array}$ & $\begin{array}{l}\text { colorless } \\
\text { colorless } \\
\text { colorless } \\
\text { colorless } \\
\text { colorless } \\
\text { colorless } \\
\text { colorless } \\
\text { colorless }\end{array}$ & $\begin{array}{l}4 \cdot 4 \\
3 \cdot 4 \\
5 \cdot 6 \\
4 \cdot 4 \\
6 \cdot 4 \\
4 \cdot 3 \\
5 \cdot 1 \\
5 \cdot 9\end{array}$ \\
\hline Antibiotics & $\begin{array}{l}\text { Gentacin } \\
\text { Gripenin } \\
\text { Iilacillin } \\
\text { Penoritin } \\
\text { Celtol } \\
\text { Keflin }\end{array}$ & $\begin{array}{c}40 \mathrm{mg} / 1 \mathrm{ml} \\
1 \mathrm{~g} / 20 \mathrm{ml} \\
1 \mathrm{~g} / 10 \mathrm{ml} \\
1 \mathrm{~g} / 20 \mathrm{~m} I \\
1 \mathrm{~g} / 10 \mathrm{ml} \\
1 \mathrm{~g} / 5 \mathrm{ml}\end{array}$ & $\begin{array}{l}\text { colorless } \\
\text { colorless } \\
\text { colorless } \\
\text { pale yellow } \\
\text { pale yellow } \\
\text { pale yellow }\end{array}$ & $\begin{array}{l}5 \cdot 4 \\
6 \cdot 5 \\
5 \cdot 5 \\
9 \cdot 0 \\
4 \cdot 6 \\
5 \cdot 4\end{array}$ \\
\hline $\begin{array}{l}\text { Anti- } \\
\text { neoplastic } \\
\text { agents }\end{array}$ & $\begin{array}{l}\text { Cylocide } \\
\text { Endoxan } \\
\text { Esquinon } \\
5 \text {-Fu } \\
\text { Mitomycin S } \\
\text { Oncovin }\end{array}$ & $\begin{array}{c}40 \mathrm{mg} / 2 \mathrm{ml} \\
100 \mathrm{mg} / 5 \mathrm{ml} * * \\
1 \mathrm{mg} / 5 \mathrm{ml} \\
250 \mathrm{mg} / 5 \mathrm{mI} \\
2 \mathrm{mg} / 10 \mathrm{ml} \\
1 \mathrm{mg} / 10 \mathrm{ml}\end{array}$ & $\begin{array}{l}\text { colorless } \\
\text { colorless } \\
\text { orange } \\
\text { colorless } \\
\text { blue violet } \\
\text { colorless }\end{array}$ & $\begin{array}{l}8.7 \\
6.7 \\
7.4 \\
8.5 \\
6.7 \\
5.7\end{array}$ \\
\hline Vitamins & $\begin{array}{l}\text { Ascortin } \\
\text { Flavitan } \\
\text { Metabolin G } \\
\text { Nutrase } \\
\text { Pydoxal } \\
\text { Pantol } \\
\text { Vitamedin } \\
\text { Vitaneurin }\end{array}$ & $\begin{array}{l}500 \mathrm{mg} / 2 \mathrm{ml} \\
20 \mathrm{mg} / 2 \mathrm{ml} \\
10 \mathrm{mg} / \mathrm{ml} \\
20 \mathrm{mg} / 2 \mathrm{ml} \\
10 \mathrm{mg} / \mathrm{ml} \\
250 \mathrm{mg} / \mathrm{ml} \\
1 \mathrm{vial} / 20 \mathrm{ml} \\
\text { I vial } / 20 \mathrm{ml}^{*}\end{array}$ & $\begin{array}{l}\text { colorless } \\
\text { orangish yellow } \\
\text { colorless } \\
\text { colorless } \\
\text { pale yellow } \\
\text { colorless } \\
\text { pink } \\
\text { brown }\end{array}$ & $\begin{array}{l}6.7 \\
5.6 \\
3.1 \\
3.6 \\
6.2 \\
5.8 \\
4.6 \\
3.4\end{array}$ \\
\hline The other & $\begin{array}{l}\text { Adona } \\
\text { Aspara K } \\
\text { Calcicol } \\
\text { K.C.I. } \\
\text { MDS } \\
\text { Neophyllin } \\
\text { Nicholin } \\
\text { Novo Ieparin } \\
\text { Persantin } \\
\text { Primperan } \\
\text { Tathion }\end{array}$ & $\begin{array}{c}25 \mathrm{mg} / 5 \mathrm{ml} \\
10 \mathrm{ml}(10 \%) \\
425 \mathrm{mg} / 5 \mathrm{ml} \\
20 \mathrm{ml}(15 \%) \\
300 \mathrm{mg} / 5 \mathrm{ml} \\
250 \mathrm{mg} / 10 \mathrm{ml} \\
250 \mathrm{mg} / 2 \mathrm{ml} \\
5000 \mathrm{mni} / 5 \mathrm{ml} \\
10 \mathrm{mg} / 2 \mathrm{ml} \\
10 \mathrm{mg} / 2 \mathrm{ml} \\
600 \mathrm{mg} / 10 \mathrm{ml}\end{array}$ & $\begin{array}{l}\text { orange } \\
\text { colorless } \\
\text { colorless } \\
\text { yellow } \\
\text { pale yellow } \\
\text { colorless } \\
\text { colorless } \\
\text { colorless } \\
\text { yellow } \\
\text { colorless } \\
\text { colorless }\end{array}$ & $\begin{array}{l}5 \cdot 7 \\
7.0 \\
6.4 \\
5 \cdot 6 \\
5 \cdot 8 \\
9.0 \\
7 \cdot 3 \\
6.5 \\
2.8 \\
3.3 \\
5.9\end{array}$ \\
\hline
\end{tabular}

* and ** shows that powder for injection dissolved with $20 \%$ glucose and strile water for injection. Another powder for injection dissolved with isotonic sodium chloride solution respectively. 
およびペリソリタ（以下 PST) の 8 種, 抗生剤はダンタ シン (以下 $\mathrm{GM}$ ), グリペニン (以下 $\mathrm{CBPC}$ ), リラシリ ン, ペンブリチン (以下 $\mathrm{ABPC}$ ), セルトール (以下CEC) 拉よびケフリン (以下 $\mathrm{KF}$ ) の 6 種, 抗悪性腫瘍剤はキ ロサイド，エンドキサン (以下 $\mathrm{ED}$ ), エスキノン (以下 $\mathrm{EQ}), 5-\mathrm{Fu}$ ，マイトマイシン S (以下 MMC) およびオ ンコビンの 6 種, ビタミン剤はアスコルチン, フラビタン (以下 $\left.\mathrm{VB}_{2}\right)$, 強力メタボリン $\mathrm{G}\left(\right.$ 以下 $\left.\mathrm{VB}_{1}\right)$, ヌトラー ゼ (以下 $\mathrm{NT})$, パントール (以下 $\mathrm{PO})$, ピドキサール (以下 $\left.\mathrm{VB}_{6}\right)$, ビタメジン (以下 VMD) 拈よびビタノィ リン (以下 VNU) の 8 種, ならびにその他11種の注射 剤, すなわちアドナ, アスパラ $\mathrm{K}$, カルチコール（以下 CC), K. C. L., MSD, ネオフィリン, ニコリン（以下 $\mathrm{NC}$ ), ノボヘパリン (以下 HP), ペルサンチン (以下 PS), プリンペランおよびタチオンの39種の注射剂を実 験材料とした (Table 1).

\section{2. 各 $\mathrm{pH}$ 域における安定性}

実験に先だち UKについて $0.1 \mathrm{~N}-\mathrm{HCl}, 0.1 \mathrm{~N}-\mathrm{NaOH}$ を用い $\mathrm{pH}$ 域による外観変化を調べるとともに, $\mathrm{pH} 3$, $4,5 ， 6 ， 7,8$ および 9 における24時間の安定性につい ても検討した.

\section{3. 配合試験}

UK 6,000 unit を生理食塩液（以下生食と略す）で正 確に $5 \mathrm{ml}$ に溶解し, 用時溶解の注射剂は能書の指示に 從って ED および MMC は注射用蒸留水で, VNU は $20 \%$ ブドゥ糖液に，他はすべて生食で Table 1 に示し た量にそれぞれ正確に溶解し，各試料液とした．配合は 1 バイアルまたは 1 アンプルの割合で混合し, 配合試料 原液とした. いずれも室温に放置し, 配合直後, 3,6 お よび24時間後にそれぞれサンプリングし，外観変化の観 察, $\mathrm{pH}$ の測定および UK の力価をフィブリン平板（以 下 FP と略す) 法で測定した.

\section{UK の力価の測定}

Walton らの方法 $\left.{ }^{1 \sim 3}\right)$ に従い FP を作成し, 定量に用 いた.

フィブリノーゲン溶液：ヒト・フィブリノーゲン（以 下 FG と略す） 1 バィアルに, 約 $4^{\circ}$ に保存した $1 \%$ リ 酸塩緩衝液 (以下 PB と略す) $\mathrm{pH} 7.4100 \mathrm{ml}$ を注射 筒を用いて注入し，泡立てないよらにゆるやかに注意し ながら溶解した．完全に溶解させた後，全量を $200 \mathrm{ml}$ とし, $50 \mathrm{ml}$ ずつ $100 \mathrm{ml}$ のビーカー 4 個に分注した.

トロンビン溶液：ヒト・トロンビン（ミドリ十字） 1 バイアルに PB (pH 7.4) $10 \mathrm{ml}$ を加えて溶解した.

アガロース溶液：アガロース（以下 AG と略す） 300 $\mathrm{mg}$ に $\mathrm{PB}\left(\mathrm{pH} \mathrm{7.4)} 48 \mathrm{ml}\right.$ を加えて, $100^{\circ}$ の水溶上で
ガラス棒で時々かき混ぜながら溶かして調製し，これを 各々 $12 \mathrm{ml}$ ずつ 4 本の試験管に分注した.

平板の作製： $\mathrm{FG}$ 溶液および $\mathrm{AG}$ 溶液を，それぞれ $45^{\circ}$ に調節した水溶上に 10 分間以上浸し, 溶液の温度が いずれも $45^{\circ}$ 以下に保たれていることを確認したのち, $\mathrm{AG}$ 溶液中にトロンビン溶液 $0.5 \mathrm{ml}$ ずつ加えて混和し た。直ちにその混液を FG 溶液に加え, 液が均等になる ようにガラス棒でおだやかにかき混ぜたのち，内のり $100 \times 200 \times 10 \mathrm{~mm}$ のプラスチック製の平板調製容器に 移した．この溶液が容器の隅々まで均等な厚さを保つよ らにスパーテルで拡げ，また気泡もスパーテルですばや く除いた，約15分間静置し，固化させて，4枚の平板を 作製した。なお，平板はサンプリングごとに作製した。

標準溶液㧍よび配合試料原液の添着ならびに培養 : 隌 準溶液は $50 ， 25 ， 12.5 ， 6.25$ unit $/ \mathrm{ml}$ になるよ5に生 食を用いて調製し, 各配合試料原液も慓準液の濃度範囲 に入るように生食で各々希釈し, 定量用試料液とした。 透明な平板の下に $1.5 \mathrm{~mm}$ 間隔の 方眼紙をそれぞれ置 きそその交点にマイクロピペットを用いて，1枚の平板 に堽準液および各定量用試料液を $10 \mu \mathrm{l} 3$ 点ずつ添着 し, $37^{\circ}$ で 18〜20時間培養した. 培養後, 各溶解空の直 径を測定し，それぞれ平均值を算出した。横軸にUKの 濃度 (unit $/ \mathrm{ml}$ ), 縦軸に溶解空の直径 $(\mathrm{mm})$ をとり, 片対数グラフを用いて検量線を作成した (Fig. 2). これ より定量用試料液中の unit $/ \mathrm{ml}$ を求め, 残存率は混合 前の UK の力価に対する割合で示した.

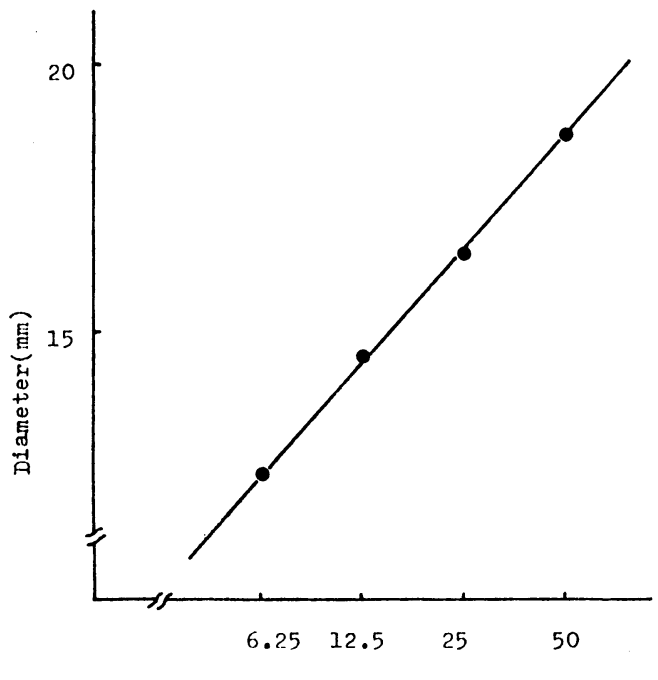

Concentration of Urokinase(unit/ml)

Fig. 2. Standard Curve of Urokinase T'ested with Fibrin-plate Method 
なお，同様に各配合剤の試料液も添着し，培盖して溶 解空を示さないことを確認した。

\section{実 結 果}

用時溶解させて用いる注射剂は生食, 注射用蒸留水打 よび $20 \%$ ブドウ糖に溶解させた. そのときの外観および $\mathrm{pH}$ の測定值を，また他の注射剂は実験に用いた $\mathrm{pH}$ と 外観を Table 1 に示した.

\section{1. 各 $\mathbf{p H}$ 城における安定性}

$\mathrm{UK}$ を生食 $5 \mathrm{ml}$ に溶解させ, 各々等分し, 一方に $0.1 \mathrm{~N}-\mathrm{HCl}$ を，他方に $0.1 \mathrm{~N}-\mathrm{NaOH}$ をそれぞれ $10 \mathrm{ml}$ ずつ加えて $\mathrm{pH}$ を測定した. $\mathrm{UK}$ は $\mathrm{pH} 1.2 \sim 12.7$ の範 明で外観変化は認められなかった (Table 2).

各 $\mathrm{pH}$ 域は $0.1 \mathrm{M}$ クェン酸および $1 \%$ ン酸塩を用 いて pH 3〜9までの各 $\mathrm{pH}$ を調製した。これらの各々 50 $\mathrm{ml}$ に UK $0.5 \mathrm{ml}$ ずつを加えた後, 室温に放置し, こ れより $0 ， 3 ， 6$ および 24 時間後に各々サンプリングし, UK の力価を測定した. その結果, UK は $\mathrm{pH} 3 \sim 9$ の 範囲で, 配合24時間後においても $90 \%$ 以上の残存率を, また室温放置の UK の生食溶液も同様に $90 \%$ 以上をそ れぞれ示し安定であった.これらの結果は J. Plong ら4) や山本ら5) の成績と一致した (Table 3).

\section{2. 配合変化試験}

補液類は実際の使用量の $1 / 10$, 他の注射剂は $1 / 2$ アン プルまたはバイアルの配合量で実験した. 外観の観察, $\mathrm{pH}$ の測定および UK の力価の測定の結果を各々 Table 4〜7 に示した.

補液類において外観変化はほとんどなく, $\mathrm{pH}$ は $\mathrm{GL}$, $\mathrm{DX}$ および $\mathrm{PZ}$ との混合ではこれら配合剤の $\mathrm{pH}$ より少 し高めであった。他は補液の $\mathrm{pH}$ に近似値を示した。

Table 2. Visible Change of Urokinase Caused by $\mathrm{pH}$ Shifts

\begin{tabular}{llcl}
\hline & $\mathrm{ml}$ & point & $\mathrm{pH}$ \\
\hline $0.1 \mathrm{~N}-\mathrm{HCl}$ & 10 & - & $7.0 \rightarrow 1.2$ \\
$0.1 \mathrm{~N}-\mathrm{NaOH}$ & 10 & - & $7.0 \rightarrow 12.7$ \\
\hline
\end{tabular}

The $\mathrm{pH}$ was shifted by addition of $0.1 \mathrm{~N}-\mathrm{HCl}$. or $0.1 \mathrm{~N}-\mathrm{NaOH}$.

Table 3. Stability of Urokinase at Various pH Levels

\begin{tabular}{|c|c|c|c|c|}
\hline \multirow[b]{2}{*}{$\mathrm{pH}$} & \multicolumn{4}{|c|}{$\frac{\text { Residual potency }(\%)}{\text { Hours after mixing }}$} \\
\hline & 0 & 3 & 6 & 24 \\
\hline 3.0 & 101 & 98 & 104 & 92 \\
\hline 4.0 & 95 & 95 & 101 & 95 \\
\hline 5.0 & 99 & 90 & 91 & 90 \\
\hline 6.0 & 97 & 94 & 105 & 91 \\
\hline 7.0 & 109 & 99 & 109 & 92 \\
\hline 8.0 & 95 & 104 & 109 & 92 \\
\hline 9.0 & 106 & 102 & 106 & 102 \\
\hline Urokinase & 100 & 105 & 95 & 97 \\
\hline
\end{tabular}

Residual potency $(\%)$ was tested with at room temperature respectively.

Ajustments of $\mathrm{pH}$ treated with sodium phosphate dibasic, potassium phosphate momobasic and citric acid. 
た， $\mathrm{ST}_{3}$ および PST との混合で，配合 6 時間後より， GL では配合24時間後に UK の力価の低下がそれぞれ認 められた (Table 4).

抗生剤において GM, CBPC および SBPC では外観, $\mathrm{pH}$ および力価共に変化は認められなかった. CEC との 混合において, $\mathrm{pH}$ の酸性側へのシフトがみられ, 力価 では配合直後に $90 \%$ 以下の残存率でその後経時的に低下 する傾向を示した．KF との混合に扒いて, 配合24時間 後に濃色変化がみられ， $\mathrm{pH}$ は経時的に酸性側へシフト した．また，力価では配合直後に 残存率がわずか $33 \%$ で，さらに経時的に変化し，24時間後では10\%以下であ った，ABPC において， $\mathrm{pH}$ はわずかながら酸性側への シフトがみられ，力価は配合直後に約 $60 \%$ に低下する が，その後大きな変化はみられなかった。

抗悪性腫演剂との混合では, 外観拝よび $\mathrm{pH}$ 共に経時
的変化は認められず，力価も配合 24 時間後にそれぞれ 90\%以上の残存率を示し安定であった (Table 5).

ビタミン剤との混合では. 外観および $\mathrm{pH}$ 共に配合 24 時間後も混合時と同様で経時的な変化はなかった。しか 乙, $\mathrm{VB}_{1}, \mathrm{VB}_{2}, \mathrm{VB}_{6}, \mathrm{VMD}$ および $\mathrm{VNU}$ は配合 6 時 間後にそれぞれ $70 \%$ 前後に，また PO では配合24時間後 に力価の低下が認められた (Table 6).

その他11種の注射剤に批いて，CC ならびに PS との 混合では, 配合直後より湜濁がみられ，CC はその後沈 殿物を生じた。 $\mathrm{pH}$ においては変化がみられなかった。

K. C. L. および NC との混合では配合 3 時間後に，また MDS および HP との混合では配合 6 時間後に，それぞ れ残存率が $90 \%$ 以下になった (Table 7).

なお，力価において配合直後に $120 \%$ 以上になった配 合例では，その直後の力価を $100 \%$ とした。

Table 4. Results of Compatibility Test with Urokinase and Infusions

\begin{tabular}{|c|c|c|c|c|c|}
\hline \multirow[b]{2}{*}{ DruEs } & \multirow[b]{2}{*}{ Measurements } & \multicolumn{4}{|c|}{ Houre after mixing } \\
\hline & & 0 & 3 & 6 & 24 \\
\hline Glunon & $\begin{array}{c}\text { pH } \\
\text { Appearance } \\
\text { Fotency }(\%)\end{array}$ & $\begin{array}{l}6.5 \\
\text { colorless } \\
96\end{array}$ & $\begin{array}{l}6.4 \\
110\end{array}$ & $\begin{array}{l}6.3 \\
107\end{array}$ & $\begin{array}{c}6.2 \\
\overrightarrow{73}\end{array}$ \\
\hline $\begin{array}{l}\text { Dextran } \\
(\text { low mol) }\end{array}$ & $\begin{array}{c}\text { pF } \\
\text { Appearance } \\
\text { Fotency }(\%)\end{array}$ & $\begin{array}{l}4.4 \\
\text { colorless } \\
116\end{array}$ & $\begin{array}{l}4.4 \\
124\end{array}$ & $\begin{array}{l}4.3 \\
\overrightarrow{129}\end{array}$ & $\begin{array}{l}4.3 \\
\overrightarrow{21}\end{array}$ \\
\hline Physisalz & $\begin{array}{c}\text { DH } \\
\text { Appearance } \\
\text { Potency }(\%)\end{array}$ & $\begin{array}{l}6.6 \\
\text { colorless } \\
110\end{array}$ & $\begin{array}{l}6.6 \\
107\end{array}$ & $\begin{array}{l}6.7 \\
\overrightarrow{118}\end{array}$ & $\begin{array}{l}6.6 \\
\overrightarrow{90}\end{array}$ \\
\hline Hartmann D & $\begin{array}{c}\text { pH } \\
\text { Apperance } \\
\text { Potency }(\%)\end{array}$ & $\begin{array}{c}4.4 \\
\text { colorless } \\
97\end{array}$ & $\begin{array}{l}4.4 \\
105\end{array}$ & $\begin{array}{l}4.4 \\
1 \overrightarrow{16}\end{array}$ & $\begin{array}{l}4.4 \\
104\end{array}$ \\
\hline Iactec & $\begin{array}{c}\text { pH } \\
\text { Appearance } \\
\text { Potency }(\%)\end{array}$ & $\begin{array}{l}6.7 \\
\text { coiorless } \\
90\end{array}$ & $\begin{array}{l}6.7 \\
\overrightarrow{99}\end{array}$ & $\begin{array}{l}6.7 \\
\overrightarrow{101}\end{array}$ & $\begin{array}{r}6.6 \\
\overrightarrow{89}\end{array}$ \\
\hline Physiosol 3 & $\begin{array}{c}\text { pH } \\
\text { Appearance } \\
\text { Potency }(\%)\end{array}$ & $\begin{array}{l}4.3 \\
\text { colorless } \\
\text { I04 }\end{array}$ & $\begin{array}{l}4.3 \\
\vec{I} 4\end{array}$ & $\begin{array}{l}4.3 \\
{ }_{104}\end{array}$ & $\begin{array}{r}4.4 \\
\overrightarrow{98}\end{array}$ \\
\hline Solita $\mathrm{T}_{3}$ & $\begin{array}{c}\text { pE } \\
\text { Appearance } \\
\text { Potency }(\%)\end{array}$ & $\begin{array}{l}5.2 \\
\text { colorless } \\
100\end{array}$ & $\begin{array}{l}5.2 \\
\overrightarrow{104}\end{array}$ & $\begin{array}{c}5.2 \\
\overrightarrow{75}\end{array}$ & $\begin{array}{l}5.2 \\
\overrightarrow{71}\end{array}$ \\
\hline Peri-Solita & $\begin{array}{c}\text { pH } \\
\text { Appearance } \\
\text { Potency }(\%)\end{array}$ & $\begin{array}{l}6.0 \\
\text { colorless } \\
114\end{array}$ & $\begin{array}{l}6.0 \\
\overrightarrow{110}\end{array}$ & $\begin{array}{l}6.7 \\
\overrightarrow{75}\end{array}$ & $\begin{array}{r}6.1 \\
\overrightarrow{78}\end{array}$ \\
\hline
\end{tabular}


Table 5. Results of Compatibility Test with Urokinase and Antibiotics, and Antineoplastics

\begin{tabular}{|c|c|c|c|c|c|}
\hline \multirow[b]{2}{*}{ Drugs } & \multirow[b]{2}{*}{ Measurments } & \multirow[b]{2}{*}{0} & \multicolumn{2}{|c|}{ Hours after mixing } & \multirow[b]{2}{*}{24} \\
\hline & & & 3 & 6 & \\
\hline Gentacin & $\begin{array}{c}\mathrm{pH} \\
\text { Appearance } \\
\text { Potency }(\%)\end{array}$ & $\begin{array}{l}6.1 \\
\text { colorless } \\
100\end{array}$ & $\begin{array}{l}6.1 \\
109\end{array}$ & $\begin{array}{l}6.1 \\
\overrightarrow{115}\end{array}$ & $\begin{array}{l}5.9 \\
\overrightarrow{92}\end{array}$ \\
\hline Gripenin & $\begin{array}{c}\mathrm{pH} \\
\text { Appearance } \\
\text { Fotency }(\%)\end{array}$ & $\begin{array}{l}68 \\
\text { pale yellow } \\
100\end{array}$ & $\underset{98}{6.9}$ & $\begin{array}{l}6.8 \\
\overrightarrow{97}\end{array}$ & $\begin{array}{l}6.5 \\
\overrightarrow{96}\end{array}$ \\
\hline Iilacillin & $\begin{array}{c}\mathrm{pH} \\
\text { Appearance } \\
\text { Potency }(\%)\end{array}$ & $\begin{array}{l}6.5 \\
\text { colorless } \\
101\end{array}$ & $\begin{array}{l}6.5 \\
\overrightarrow{103}\end{array}$ & $\begin{array}{l}6.5 \\
\overrightarrow{110}\end{array}$ & $\begin{array}{l}6.5 \\
109\end{array}$ \\
\hline Penbritin & $\begin{array}{c}\mathrm{pH} \\
\text { Appearance } \\
\text { Potiency }(\%)\end{array}$ & $\begin{array}{l}9.0 \\
\text { paie yellow } \\
57\end{array}$ & $w \underset{56}{8.6}$ & $\begin{array}{c}8.5 \\
\overrightarrow{58}\end{array}$ & $\begin{array}{l}8.3 \\
\overrightarrow{46}\end{array}$ \\
\hline Celtol & $\begin{array}{c}\mathrm{pH} \\
\text { Appearance } \\
\text { Potency }(\%)\end{array}$ & $\begin{array}{r}6.2 \\
\text { pale yellow } \\
88\end{array}$ & $\begin{array}{l}5.5 \\
\overrightarrow{62}\end{array}$ & $\begin{array}{l}5.5 \\
\overrightarrow{59}\end{array}$ & $\begin{array}{l}4.5 \\
\overrightarrow{49}\end{array}$ \\
\hline Keflin & $\begin{array}{c}\mathrm{pH} \\
\text { Appearance } \\
\text { Potency }(\%)\end{array}$ & $\begin{array}{r}6.8 \\
\text { paie yellow } \\
33\end{array}$ & $\begin{array}{r}6.5 \\
\overrightarrow{26}\end{array}$ & $\begin{array}{l}6.1 \\
\overrightarrow{12}\end{array}$ & $\begin{array}{c}5.0 \\
\text { yeilow }\end{array}$ \\
\hline Cylocide & $\begin{array}{c}\mathrm{pH} \\
\text { Appearance } \\
\text { Potency }(\%)\end{array}$ & $\begin{array}{l}7.0 \\
\text { colorless } \\
100\end{array}$ & $\underset{100}{7.1}$ & $\underset{93}{7.1}$ & $\begin{array}{c}7.0 \\
\overrightarrow{98}\end{array}$ \\
\hline Endoxan & $\begin{array}{c}\mathrm{pH} \\
\text { Appearance } \\
\text { Potency }(\%)\end{array}$ & $\begin{array}{l}7.0 \\
\text { colorless } \\
95\end{array}$ & $\begin{array}{l}7.0 \\
1 \overrightarrow{00}\end{array}$ & $\begin{array}{l}6.9 \\
\overrightarrow{11}\end{array}$ & $\begin{array}{l}6.7 \\
\overrightarrow{19}\end{array}$ \\
\hline Esquinon & $\begin{array}{c}\mathrm{pH} \\
\text { Appearance } \\
\text { Potency }(\%)\end{array}$ & $\begin{array}{c}7.2 \\
\text { orange } \\
99\end{array}$ & $\begin{array}{l}7.2 \\
\overrightarrow{I I I}\end{array}$ & $\begin{array}{l}7.2 \\
\overrightarrow{12}\end{array}$ & $\begin{array}{l}7.1 \\
141\end{array}$ \\
\hline 5-Fu & $\begin{array}{c}\mathrm{pH} \\
\text { Appearance } \\
\text { Potency }(\%)\end{array}$ & $\begin{array}{l}8.4 \\
\text { colorless } \\
100\end{array}$ & $\begin{array}{l}8.4 \\
106\end{array}$ & $\begin{array}{l}8.4 \\
106\end{array}$ & $\begin{array}{c}8.4 \\
\overrightarrow{93}\end{array}$ \\
\hline Mitomycin $S$ & $\begin{array}{c}\mathrm{pH} \\
\text { Appearance } \\
\text { Potency }(\%)\end{array}$ & $\begin{array}{r}7.0 \\
\text { blue violet } \\
99\end{array}$ & $t \overrightarrow{1.0}$ & $\begin{array}{c}7.0 \\
\overrightarrow{99}\end{array}$ & $\begin{array}{l}7.0 \\
107\end{array}$ \\
\hline Oncovin & $\begin{array}{c}\text { pH } \\
\text { Appearance } \\
\text { Potency }(\%)\end{array}$ & $\begin{array}{l}6.9 \\
\text { colorless } \\
100\end{array}$ & $\begin{array}{l}7.0 \\
101\end{array}$ & $\begin{array}{l}7.0 \\
109\end{array}$ & $\begin{array}{r}6.9 \\
\overrightarrow{96}\end{array}$ \\
\hline
\end{tabular}


Table 6. Results of Compatibility Test with Urokinase and Vitamins

\begin{tabular}{|c|c|c|c|c|c|}
\hline \multirow[b]{2}{*}{ Drugs } & \multirow[b]{2}{*}{ Measurement } & \multirow[b]{2}{*}{0} & \multicolumn{3}{|c|}{ Hours after mixing } \\
\hline & & & 3 & 6 & 24 \\
\hline Ascortin & $\begin{array}{c}\mathrm{pH} \\
\text { Appearance } \\
\text { Potency }(\%)\end{array}$ & $\begin{array}{l}6.9 \\
\text { colorless } \\
100\end{array}$ & $\begin{array}{l}7.1 \\
102\end{array}$ & $\begin{array}{l}7.1 \\
\overrightarrow{98}\end{array}$ & $\begin{array}{l}6.8 \\
\overrightarrow{108}\end{array}$ \\
\hline Flavitan & $\begin{array}{c}\mathrm{pH} \\
\text { Appearance } \\
\text { Potency }(\%)\end{array}$ & $\begin{array}{l}6.9 \\
\text { ora. yellow } \\
\text { I05 }\end{array}$ & $\begin{array}{l}6.9 \\
102\end{array}$ & $\begin{array}{l}6.8 \\
\overrightarrow{71}\end{array}$ & $\begin{array}{l}6.9 \\
\overrightarrow{59}\end{array}$ \\
\hline Metabolin G & $\begin{array}{c}\text { pH } \\
\text { Appearance } \\
\text { Potency }(\%)\end{array}$ & $\begin{array}{l}6.3 \\
\text { colorless } \\
96\end{array}$ & $\begin{array}{l}6.3 \\
\overrightarrow{96}\end{array}$ & $\begin{array}{l}6.3 \\
\overrightarrow{78}\end{array}$ & $\begin{array}{l}6.3 \\
\overrightarrow{71}\end{array}$ \\
\hline Nutrase & $\begin{array}{c}\text { pH } \\
\text { Appearance } \\
\text { Potency }(\%)\end{array}$ & $\begin{array}{l}5.8 \\
\text { colorless } \\
95\end{array}$ & $\begin{array}{l}5.8 \\
\overrightarrow{102}\end{array}$ & $\begin{array}{l}5.8 \\
\overrightarrow{124}\end{array}$ & $\begin{array}{l}5.4 \\
\overrightarrow{129}\end{array}$ \\
\hline Pantol & $\begin{array}{l}\text { pH } \\
\text { Appearance } \\
\text { Potency }(\%)\end{array}$ & $\begin{array}{l}6.8 \\
\text { colorless } \\
98\end{array}$ & $\begin{array}{l}6.8 \\
7 \\
95\end{array}$ & $\begin{array}{c}6.8 \\
\overrightarrow{91}\end{array}$ & $\begin{array}{l}6.7 \\
\overrightarrow{6} 6\end{array}$ \\
\hline Pydoxal & $\begin{array}{c}\text { pH } \\
\text { Appearance } \\
\text { Potency }(\%)\end{array}$ & $\begin{array}{l}6: 6 \\
\text { pale yellow } \\
100\end{array}$ & $\begin{array}{l}6.5 \\
104\end{array}$ & $\begin{array}{c}6.4 \\
\overrightarrow{78}\end{array}$ & $\begin{array}{l}6.3 \\
\overrightarrow{52}\end{array}$ \\
\hline Vitamedin & $\begin{array}{l}\text { pH } \\
\text { Appearance } \\
\text { Potency }(\phi)\end{array}$ & $\begin{array}{r}4.8 \\
\text { pink } \\
112\end{array}$ & $\begin{array}{l}4.8 \\
121\end{array}$ & $\begin{array}{c}4.8 \\
\overrightarrow{75}\end{array}$ & $\begin{array}{c}4.8 \\
\overrightarrow{81}\end{array}$ \\
\hline Vitanourin & $\begin{array}{c}\mathrm{pH} \\
\text { Appearance } \\
\text { Potency }(\%)\end{array}$ & $\begin{array}{c}4.4 \\
\text { brown } \\
100\end{array}$ & $\begin{array}{c}4.4 \\
\overrightarrow{93}\end{array}$ & $\begin{array}{c}4.4 \\
\overrightarrow{66}\end{array}$ & $\begin{array}{l}4.5 \\
\overrightarrow{7} \\
71\end{array}$ \\
\hline
\end{tabular}

ora. yellow: orangish yellow

\section{考、察}

UK と 39 種の注射剤との配合变化を検討した結果, $\mathrm{KF}$ との混合で配合24時間後に濃色変化か認められた. この变化は，通常 $\mathrm{KF}$ を溶解し，24時間放置しておいて も琶められる. 従って UK との混合による変化とは必 ずしもいえない。

$\mathrm{CC}$ の主成分であるグルコン酸カルシウムの水に対す る溶解度は $1 \mathrm{~g} / 30 \mathrm{ml}$ である。注射剂 $8.5 \sim 10 \mathrm{w} / \mathrm{v} \%$ の濃度は過飽和状態で結晶が析出しやすいといわれてお り, ${ }^{6)} \mathrm{CC}$ との混合による配合直後よりの白濁はUK の 力価の低下が認められないことから，CC の溶解度の変 化に基因するものと推測される.

PS との混合に护外観変化は PS が $\mathrm{pH} 2.8$ と強
酸性を示し，自身よりフルカリ性の薬剤の配合には注意 が必要であるといわれている. ${ }^{6)}$ 混合により $\mathrm{pH} 2.8$ か ら $\mathrm{pH} 4.6$ に変動したため PS の主成分であるジピリダ モールが析出し，黄濁したるのと考えられる。

$\mathrm{ST}_{3}, \mathrm{PST}, \mathrm{VB}_{1}, \mathrm{VB}_{2}, \mathrm{VB}_{6}, \mathrm{VMD}, \mathrm{VNU}, \mathrm{MDS}$ および HD との混合において配合 6 時間後に，K.C.L. および NC との混合で配合 3 時間後に，また CEC, KF および ABPC との混合で配合直後よりそれぞれ力価の 低下がみられた。特に KF においては配合直後より低 下し，24時間後ではわずか10\%以下の残存率であった. UK は $\mathrm{pH} 3 \sim 9$ の範囲で安定であったことから，これ らの UK の力価の低下は $\mathrm{pH}$ による影響ではなく, 配 合剂との間の化学的または物理的変化に基因すると思わ れる. DX，ED，EQ および NT との混合において力価 
Table 7. Results of Compatibility Test with Urokinase and 11 Kinds of Injection

\begin{tabular}{|c|c|c|c|c|c|}
\hline \multirow[b]{2}{*}{ Drugs } & \multirow[b]{2}{*}{ Neasurments } & \multirow[b]{2}{*}{0} & \multicolumn{2}{|c|}{ Hours after mixing } & \multirow[b]{2}{*}{24} \\
\hline & & & 3 & 6 & \\
\hline Adona & $\begin{array}{c}\text { pH } \\
\text { Appearance } \\
\text { Potency }(\%)\end{array}$ & $\begin{array}{c}6.8 \\
\text { orange } \\
103\end{array}$ & $\begin{array}{l}6.8 \\
\overrightarrow{97}\end{array}$ & $\begin{array}{l}6.8 \\
\overrightarrow{97}\end{array}$ & $\begin{array}{l}6.8 \\
\overrightarrow{99}\end{array}$ \\
\hline Aspara $\mathrm{K}$ & $\begin{array}{c}\mathrm{pH} \\
\text { Aopearance } \\
\text { Potency }(\%)\end{array}$ & $\begin{array}{l}6.9 \\
\text { colorless } \\
100\end{array}$ & $\begin{array}{c}6.8 \\
\overrightarrow{9}\end{array}$ & $\begin{array}{l}6.9 \\
\overrightarrow{95}\end{array}$ & $\begin{array}{c}6.8 \\
\overrightarrow{91}\end{array}$ \\
\hline Calcicol & $\begin{array}{c}\text { pH } \\
\text { Appearance } \\
\text { Potency }(\%)\end{array}$ & $\begin{array}{r}6.3 \\
\text { white tur. } \\
106\end{array}$ & $\begin{array}{l}6.3 \\
\overrightarrow{102}\end{array}$ & $\begin{array}{c}6.3 \\
\overrightarrow{93}\end{array}$ & $\begin{array}{c}5.9 \\
\text { Preci. } \\
93\end{array}$ \\
\hline K.C.I. & $\begin{array}{c}\mathrm{pH} \\
\text { Appearance } \\
\text { Potency }(\%)\end{array}$ & $\begin{array}{c}6.5 \\
\text { yeliow } \\
92\end{array}$ & $\begin{array}{c}6.5 \\
7 \\
59\end{array}$ & $\begin{array}{c}6.5 \\
\overrightarrow{32}\end{array}$ & $\begin{array}{c}6.5 \\
\overrightarrow{3} 1\end{array}$ \\
\hline MDS & $\begin{array}{c}\text { pH } \\
\text { Appearance } \\
\text { Potency }(\%)\end{array}$ & $\begin{array}{l}6.9 \\
\text { colorless } \\
103\end{array}$ & $\begin{array}{l}6.9 \\
110\end{array}$ & $\begin{array}{l}6.9 \\
\overrightarrow{8} \\
82\end{array}$ & $\begin{array}{c}6.9 \\
7 \\
82\end{array}$ \\
\hline Neophyllin & $\begin{array}{c}\mathrm{pH} \\
\text { Appearance } \\
\text { Potency }(\%)\end{array}$ & $\begin{array}{l}9.0 \\
\text { colorless } \\
100\end{array}$ & $\begin{array}{c}9.0 \\
\overrightarrow{92}\end{array}$ & $\begin{array}{r}9.0 \\
\overrightarrow{9}\end{array}$ & $\begin{array}{l}9.0 \\
\overrightarrow{105}\end{array}$ \\
\hline Nicholin & $\begin{array}{c}\mathrm{pH} \\
\text { Appearance } \\
\text { Potency }(\%)\end{array}$ & $\begin{array}{c}7.0 \\
\text { colorless } \\
90\end{array}$ & $\begin{array}{c}7.0 \\
\overrightarrow{79}\end{array}$ & $\begin{array}{l}7.0 \\
\overrightarrow{75}\end{array}$ & $\begin{array}{c}7.0 \\
\overrightarrow{80}\end{array}$ \\
\hline Novo Heparin & $\begin{array}{c}\mathrm{pH} \\
\text { Appearance } \\
\text { Potency }(\%)\end{array}$ & $\begin{array}{l}7.0 \\
\text { colorless } \\
\text { I00 }\end{array}$ & $\begin{array}{l}\overrightarrow{7.0} \\
103\end{array}$ & $\begin{array}{l}7.0 \\
7 \\
80\end{array}$ & $\begin{array}{l}7.1 \\
\overrightarrow{76}\end{array}$ \\
\hline Persantin & $\begin{array}{c}\mathrm{pH} \\
\text { Appearance } \\
\text { Potency }(\%)\end{array}$ & $\begin{array}{c}4.8 \\
\text { Yeliow tur. } \\
98\end{array}$ & $\begin{array}{c}4.9 \\
\overrightarrow{92}\end{array}$ & $\begin{array}{l}4.7 \\
\overrightarrow{90}\end{array}$ & $\begin{array}{c}4.6 \\
\overrightarrow{90}\end{array}$ \\
\hline Primperan & $\begin{array}{c}\mathrm{pH} \\
\text { Appearance } \\
\text { Potency }(\%)\end{array}$ & $\begin{array}{l}6.7 \\
\text { colorless } \\
100\end{array}$ & $\begin{array}{l}6.7 \\
\overrightarrow{10}\end{array}$ & $\begin{array}{c}6.7 \\
7 \\
98\end{array}$ & $\begin{array}{c}6.8 \\
\overrightarrow{98}\end{array}$ \\
\hline Tathion & $\begin{array}{c}\mathrm{pH} \\
\text { Appearance } \\
\text { Potency }(\%)\end{array}$ & $\begin{array}{l}6.5 \\
\text { colorless } \\
100\end{array}$ & $\begin{array}{l}6.5 \\
\overrightarrow{107}\end{array}$ & $\begin{array}{c}6.5 \\
\overrightarrow{93}\end{array}$ & $\begin{array}{c}6.5 \\
39\end{array}$ \\
\hline
\end{tabular}

Tur. : turbidity, preci. : precipitation

に経時的な上昇が認められた．配合前にこれらの注射剤 は溶解空を示さなかったことから混合により拻散性が増 大したためではないかと思われる。

\section{結論}

ウロキナーゼと39種の注射剤との配合変化を検討した
結果は次のとおりである.

1. 外観変化のみられたカルチコール，ペルサンチン ならびに力価の著明な低下が認められたセルトール，ケ フリン, ペンブリチン, K.C.L. およびニュリンとの直 接の混合使用は避けるべきである.

2. 配合 6 時間後に力価の低下がみられたソリタ $T_{8}$, 
ペリソリタ, フラビタン, 強力メタボリン G, MDS お よびノボヘパリンは混合使用にあたっては十分留意する 必要がある.

暗辞 本研究にあたり, ウロキナーゼの標品を提供さ れた株式会社ミドリ十字に深謝いたします。

\section{文献}

1) P. L. Walton: Clin. Chim. Acta, 13 (5), 680
(1966).

2) N. A. Marsh : Thromb. Diath Hoemr., 31, 75 (1972).

3）西崎笹夫, 川村次良 : 医薬品研究， 5 (3), 295 (1974).

4) J. Plong, N. D. Kjeldgaard : Biochem. Biophys. Acta, 24, 278 (1957).

5) 山本勝義, 藤 進: 病院薬学, 5(1), 13(1979).

6) 福島嗐行監修：注射薬の配合变化, p. 20, メディ カルプランニング, 1977. 